\title{
Shear Capacity of Reinforced Concrete Pile Caps
}

\begin{abstract}
Jing Cao
Research Student

University of Southampton

UNITED KINGDOM

cj259@soton.ac.uk
\end{abstract}

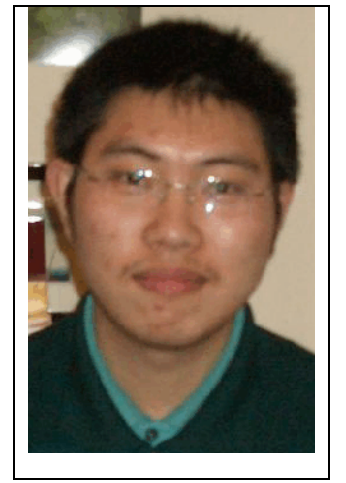

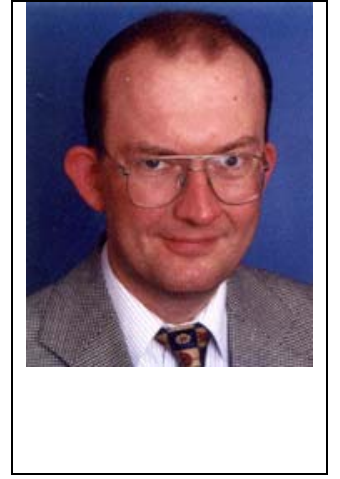

\section{Summary}

Alan G. Bloodworth

Lecturer

University of Southampton

UNITED KINGDOM

A.G.Bloodworth@soton.ac.uk

Discrepancies exist between UK design codes for the prediction of pile cap shear strength. A series of reduced scale pile cap experiments to investigate shear strength have been performed. Results from seven samples are presented. Details of test methodology and procedure are shown. Final crack distributions show that pile caps under wall load behave close to simply supported twodimensional deep beams, except for hogging cracks over the pile head indicating the existence of moment restraint at the piles. Results for failure load indicate that pile cap shear strength is at least two to three times higher than current code predictions from semi-empirical formulae. The truss method is shown to be more reliable to predict pile cap shear strength than bending theory.

Keywords: pile cap; shear; truss method; shear enhancement factor.

\section{Introduction}

A pile cap (Figure 1) is a stocky reinforced structure which spreads and distributes the load from a column or bridge pier downwards into supporting piles. Unlike standard deep beams, pile caps are relatively wide, with a width comparable to their span, contain relatively low reinforcement and in particular normally no transverse shear reinforcement [1].

Discrepancies exist in the provisions for the design of reinforced concrete pile caps for shear strength between the two UK codes for structural concrete design, BS 8110 and BS 5400. These discrepancies have arisen in the historical development of the codes, and the implication is that one code is unsafe or the other is over-conservative [2]. The overall aim of this research has been to investigate the real shear resistance of pile cap in order to resolve the contradiction between the codes.

A number of laboratory experiments on shear capacity of pile caps have been carried out in the last five decades. A variety of cap forms, reinforcement layouts, loading conditions and pile supporting conditions were used. Clarke [3] tested fifteen full size reinforced concrete pile caps, each with four piles, varying pile spacing, reinforcement layout and type of anchorage (from nil anchorage to full plus bob). Hobbs and Stein [4] tested about seventy one-third-scale two-pile caps to verify a permissible stress design method based on elastic analysis. Blevot and Fremy [5] tested about one hundred caps to verify a truss analogy method. Nine one-third scale four-pile caps were tested by Sabins and Gogate [6] together with finite element analysis. In order to investigate the strut-and-tie models contained in the ACI Building Code and Canadian concrete code, Adebar, Kuchma and Collins [1] tested six full scale pile caps, concentrating on the cap's effective depth factor rather than emphasizing the amount of longitudinal reinforcement. 


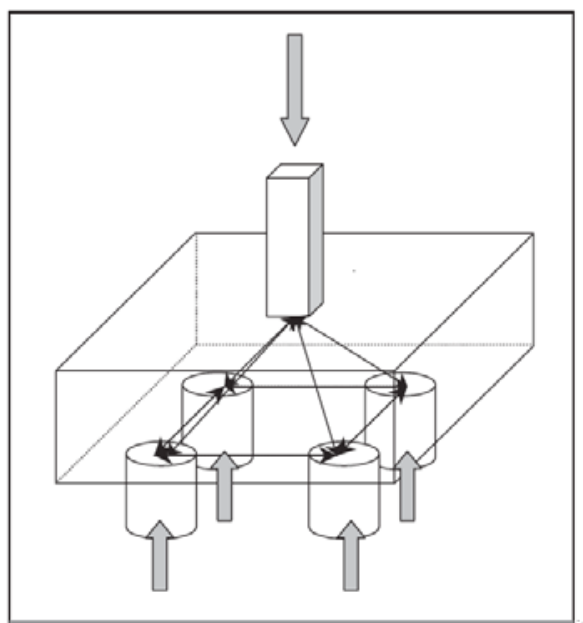

Fig. 1 A Simplified Pile Cap Model

A total of eighteen pile cap specimens have been tested at Southampton, with varying cap dimensions (depth, length and width), pile diameter and pile spacing. Of these eighteen, seven clearly achieved shear failure. The experiments were planned to investigate the validity of predictions of pile cap shear capacity in the two UK design codes, both from semi-empirical formulae based on bending theory, and from the truss method of design.

\section{Current design methods}

The UK building code,BS8110:Part 1[7], and the bridge code, BS5400:Part 4 [8], give similar semi-empirical formulae for pile cap shear design based on bending theory. The major differences are firstly the definition of pile cap width for which the shear enhancement factor is applied, and secondly the representation of size effect (shear strength reducing when the cap depth increases).

The two formulae are given below:

$v_{c}=\frac{0.79}{\gamma_{m}}\left(\frac{100 A_{s}}{b d}\right)^{1 / 3}\left(\frac{400}{d}\right)^{1 / 4}\left(\frac{2 d}{a_{v}}\right)$

$v_{c}=\frac{0.27}{\gamma_{m}}\left(\frac{100 A_{s}}{b d}\right)^{1 / 3}\left(f_{c u}\right)^{1 / 3}\left(\frac{500}{d}\right)^{1 / 4}\left(\frac{2 d}{a_{v}}\right) \quad(\mathrm{BS} 5400)$

where $v_{c}$ is nominal design shear stress uniformly distributed on a vertical section of cap of width $b$ and effective height $d$ under design shear load $V$ (i.e. $v_{c}=\frac{V}{b d}$ ); $A_{s}$ is the total area of main reinforcement; $a_{v}$ is the shear span, defined as the distance between the edge of the loaded area and $20 \%$ of the pile diameter inside the pile inner edge; $\gamma_{m}$ is the partial factor on material strength (taken as 1.25 in both codes) and $f_{c u}$ is the design strength of concrete. Key dimensions are depicted in Figure 2. BS8110 states that depth factor $\left(\frac{400}{d}\right)^{1 / 4}$ is not to be less than 0.67 , while for BS5400 the depth factor $\left(\frac{500}{d}\right)^{1 / 4}$ is not to be less than 0.70 . BS8110 also states that $v_{c}$ should be multiplied with a factor $\left(\frac{f_{c u}}{25}\right)^{1 / 3}$ if concrete characteristic strength is bigger than $25 \mathrm{~N} / \mathrm{mm}^{2}$. The shear enhancement factor $\left(\frac{2 d}{a_{v}}\right)$ serves to increase the shear strength when the shear span $a_{v}$ is less than $2 d$. The key difference between the two codes lies here, in the width of the cap over which this shear enhancement factor needs to be applied. BS8110 suggests a strip of width three times the pile diameter centred on each pile, whereas BS5400 suggests a strip of width just equal to the pile diameter. This gives rise to a big difference in shear strength prediction between two codes, especially when the transverse pile spacing exceeds three times the pile diameter. Key dimensions mentioned above are shown in Figure 2. 
As an alternative to shear design based on beam theory, the truss analogy (strut-and-tie) method is also permitted in BS8110 and BS5400. This method emphasizes a different physical explanation of load carrying capacity, based on an assumed compressive stress trajectory in the concrete, reacted by tension in the main reinforcement, as indicated in Figure 1. Both codes imply that the tension force is taken mainly by reinforcement above the pile head - BS8110 suggests reinforcement in a strip of width three times the pile diameter centred on each pile is effective (analogous to the width of shear enhancement), while in BS5400, all reinforcement can be taken into account provided 80\% of it is placed in strips anchored directly over the piles. KK

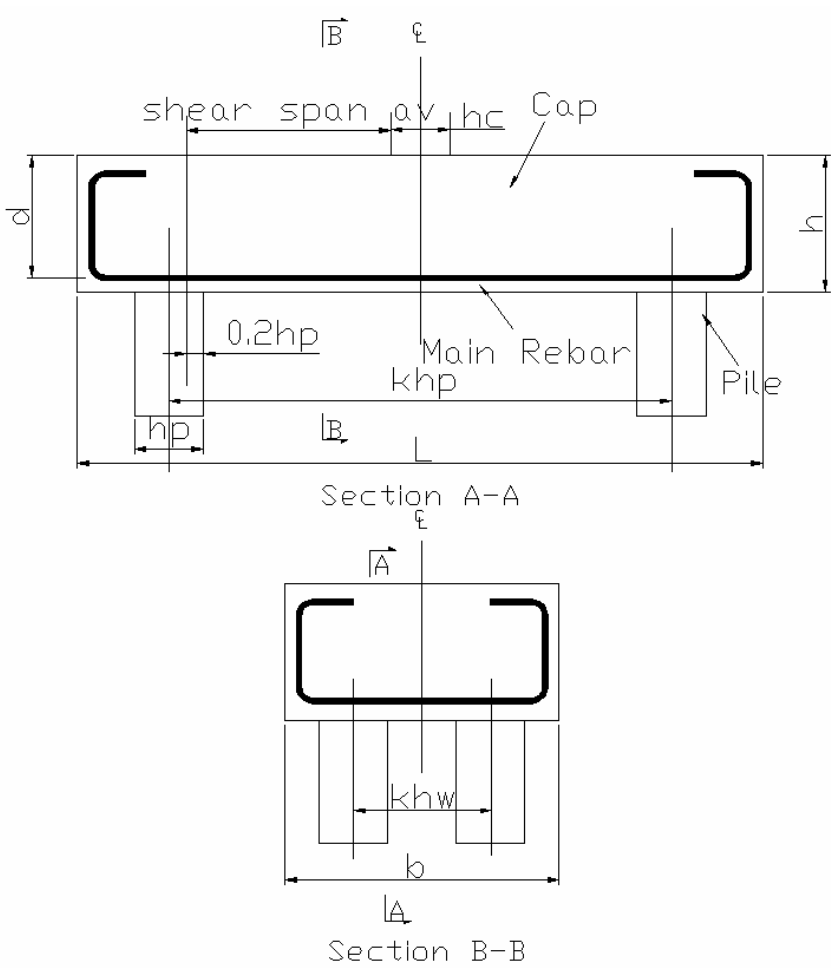

\section{Specimen Design}

The results of two series of pile cap tests will be reported on here - those specimens for which shear failure (as opposed to bending failure) was most evident.

Series A, specimens B4A1 to B4A5, are used to investigate the effect of varying shear enhancement factor on cap shear capacity. Pile spacing $k h_{p}$ is chosen so that $\left(\frac{2 d}{a_{v}}\right)$ varies

from 1.3 to 3.6. Series B, specimens B4B2 and $\mathrm{B} 4 \mathrm{~B} 3$ together with $\mathrm{B} 4 \mathrm{~A} 2$, are designed to investigate the ratio $A$ of width on which shear enhancement applies divided by overall cap width (see Table 1). This is achieved by keeping the same depth and pile diameter as Series A and the same longitudinal pile

Fig. 2 Key Dimensions of Pile Cap spacing $k h_{p}$ as B4A2, but increasing the transverse pile spacing, $k h_{w}$. Key cap dimensions, depth factor and shear enhancement factor are listed in Table 1.

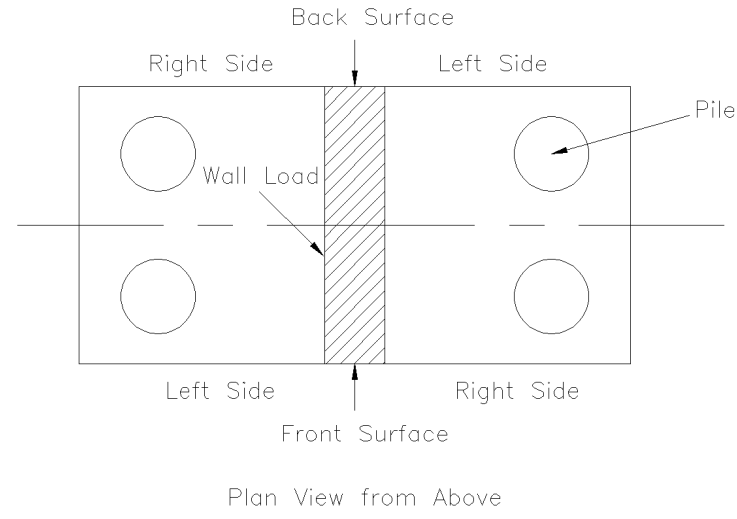

Fig. 3 Load Type
Pile caps may be loaded either by a concentrated load modelling a discrete column, or a strip or wall load distributed across the cap width. The cap capacity under a concentrated load can be limited in some instances by punching shear failure, and therefore a distributed wall load was applied in these tests, as shown in Figure 3. 
Table 1 Key Dimensions of Pile Cap Specimens

\begin{tabular}{|c|c|c|c|c|c|c|c|c|}
\hline $\begin{array}{l}\text { Pile Cap } \\
\text { Specimen } \\
\text { Number }\end{array}$ & $\begin{array}{c}\text { Pile } \\
\text { Cap } \\
\text { Depth, } \\
h \\
(\mathrm{~mm})\end{array}$ & $\begin{array}{c}\text { Effective } \\
\text { Depth } \\
d(m m)\end{array}$ & $\begin{array}{c}\text { Pile } \\
\text { Cap } \\
\text { Length, } \\
L \\
(\mathrm{~mm})\end{array}$ & $\begin{array}{c}\text { Pile } \\
\text { Cap } \\
\text { Width, } \\
b \\
(\mathrm{~mm})\end{array}$ & $\begin{array}{c}\text { Pile } \\
\text { Diameter } \\
h_{p}(m m)\end{array}$ & $\begin{array}{c}\text { Longitudinal } \\
\text { Pile Spacing } \\
\qquad h_{p}(\mathrm{~mm})\end{array}$ & $\begin{array}{c}\text { Width } \\
\text { Pile } \\
\text { Spacing } \\
k h_{w}(\mathrm{~mm})\end{array}$ & $\begin{array}{c}\text { Column(load) } \\
\text { Width } \\
h_{c}(\mathrm{~mm})\end{array}$ \\
\hline B4A1 & 230 & 199 & 1100 & 500 & 130 & 800 & 300 & 100 \\
\hline B4A2 & 230 & 199 & 950 & 500 & 130 & 650 & 300 & 100 \\
\hline B4A3 & 230 & 199 & 850 & 500 & 130 & 550 & 300 & 100 \\
\hline B4A4 & 230 & 199 & 800 & 500 & 130 & 500 & 300 & 100 \\
\hline B4A5 & 230 & 199 & 700 & 500 & 130 & 400 & 300 & 100 \\
\hline B4B2 & 230 & 200 & 950 & 650 & 130 & 650 & 450 & 100 \\
\hline B4B3 & 230 & 200 & 950 & 750 & 130 & 650 & 550 & 100 \\
\hline
\end{tabular}

\begin{tabular}{ccccccc}
\hline $\begin{array}{c}\text { Pile Cap } \\
\text { Specimen } \\
\text { Number }\end{array}$ & $\begin{array}{c}\text { Depth } \\
\text { Factor } \\
\text { Based } \\
\text { On } \\
\text { BS8110 }\end{array}$ & $\begin{array}{c}\text { Depth } \\
\text { Factor } \\
\text { Based } \\
\text { On }\end{array}$ & $\begin{array}{c}\text { Shear } \\
\text { BS5400 }\end{array}$ & $\begin{array}{c}\text { Shement } \\
\text { Factor } \frac{2 d}{a_{v}}\end{array}$ & & \multicolumn{2}{c}{$\begin{array}{c}\text { Shear Enhancement } \\
\text { Application Ratio } A\end{array}$} \\
\hline B4A1 & 2.01 & 1.26 & 1.28 & & 1 & BS8110 \\
B4A2 & 2.01 & 1.26 & 1.69 & & BS5400 \\
B4A3 & 2.01 & 1.26 & 2.14 & 1 & 0.52 \\
B4A4 & 2.01 & 1.26 & 2.47 & 1 & 0.52 \\
B4A5 & 2.01 & 1.26 & 3.59 & 1 & 0.52 \\
B4B2 & 2 & 1.26 & 1.69 & 0.908 & 0.52 \\
B4B3 & 2 & 1.26 & 1.69 & 0.787 & 0.40 \\
\hline
\end{tabular}

The concrete characteristic strength was specified as 20MPa in order to obtain a shear capacity low enough for the capability of the testing machine. Three testing cubes were produced with each specimen, which were tested at the same time as the experiment. The actual concrete strength was taken as the mean value of these cube tests.

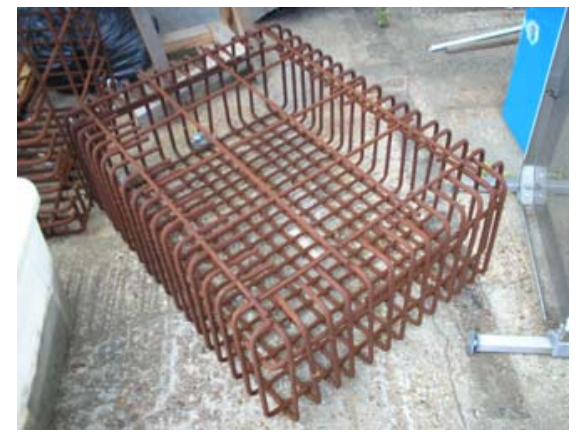

Fig. 4 Typical Reinforcement Cage
Reinforcement, in the form of ' $U$ '-bars bent up to offer full anchorage, is distributed uniformly in both longitudinal and transverse directions with spacing 50mm (see Figure 4). Reinforcement of type T12 (diameter $12 \mathrm{~mm}$ ) was used in specimens B4A1 - B4A5, and type T10 (diameter 10mm) was used in specimens B4B2 and B4B3. The yield strength of the T12 reinforcement was obtained from a mean of sixteen tensile tests as $547 \mathrm{MPa}$. The value for the T10 reinforcement was assumed to be the same. Table 2 shows the concrete and reinforcement properties assumed for the specimens. The four piles are also reinforced and cast integral with the cap body. 
Table 2 Reinforcement and Concrete Properties

\begin{tabular}{cccccc}
\hline $\begin{array}{c}\text { Pile Cap } \\
\text { Specimen } \\
\text { Number }\end{array}$ & $\begin{array}{c}\text { Reinforcement } \\
\text { Type and } \\
\text { Diameter }\end{array}$ & $\begin{array}{c}\text { Reinforcement } \\
\text { Design } \\
\text { Characteristic } \\
\text { Strength } \\
f_{y}(M P a)\end{array}$ & $\begin{array}{c}\text { Measured } \\
\text { Yield } \\
\text { Strength } \\
(M P a)\end{array}$ & $\begin{array}{c}\text { Concrete } \\
\text { Design } \\
\text { Characteristic } \\
\text { Strength } \\
f_{c u}(M P a)\end{array}$ & $\begin{array}{c}\text { Measured } \\
\text { Concrete Cube } \\
\text { Compressive } \\
\text { Strength }(M P a)\end{array}$ \\
\hline B4A1 & T12 & 460 & 547 & 20 & 20.3 \\
B4A2 & T12 & 460 & 547 & 20 & 21.8 \\
B4A3 & T12 & 460 & 547 & 20 & 24.3 \\
B4A4 & T12 & 460 & 547 & 20 & 24.4 \\
B4A5 & T12 & 460 & 547 & 20 & 23 \\
B4B2 & T10 & 460 & 547 & 20 & 25.6 \\
B4B3 & T10 & 460 & 547 & 20 & 24.7 \\
\hline
\end{tabular}

\section{Experimental Procedure and Instrumentation}

The specimens were loaded in a 150 tonne Instron testing machine in the Heavy Structures

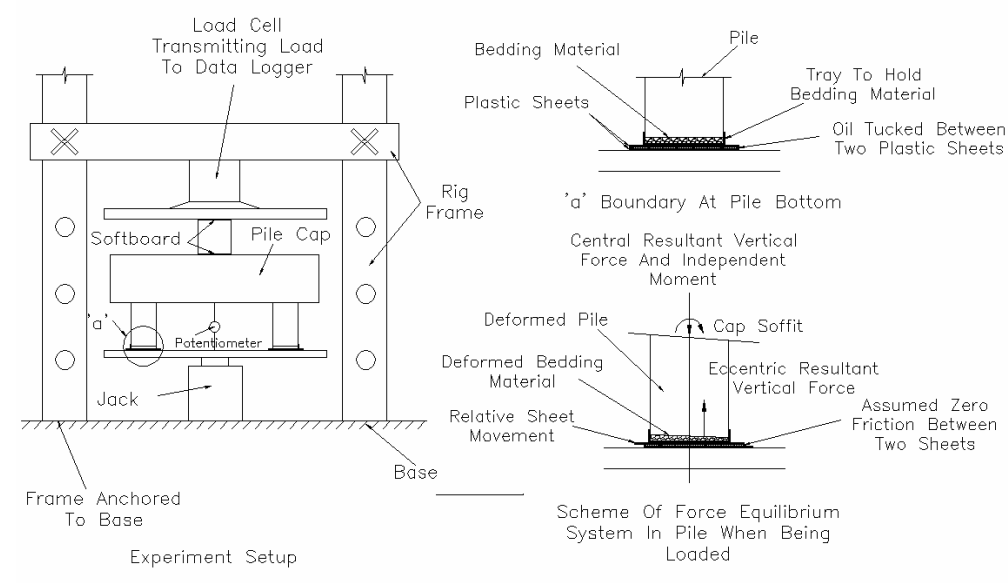

Laboratory at Southampton University (Figure 5).

The samples placed on the bed of the testing machine with a layer of bedding material in a hardboard tray beneath each pile, in order to account for slight variations in the pile lengths and to ensure even load distribution over each pile, avoiding stress concentrations leading to local crushing. Beneath the hardboard tray was two plastic sheets with oil in between, to minimise the friction and

Fig. 5 Specimen Set Up And Pile Boundary Condition thus the horizontal restraint to each pile.

Soft boards were introduced between the wall load beam and the top surface of the cap and the upper plate of the testing machine to obtain a uniform load distribution across the cap.

The support conditions provided by the piles to the cap can influence its shear and bending behaviour. The fully integral pile connection used in this case can give independent vertical force and moment reactions to the cap, with the whole structure close to acting as a rigid frame with

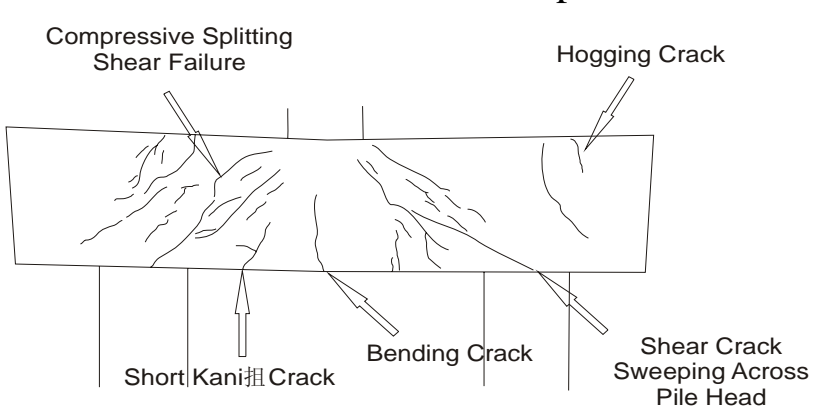
rotation of the cap restrained (Figure 5).

During the initial stage of loading, when the structure deformed linearly, load control was used with the load increased in equal increments ranging from $25 \mathrm{kN}$ to $100 \mathrm{kN}$ depending on the specimen.

After judging that the structure behaviour has developed into yield, load control was changed to

Fig. 6 Types of Cracking Observed

displacement control with step size ranging from $0.25 \mathrm{~mm}$ to $1.5 \mathrm{~mm}$. The loading rate was kept slow 


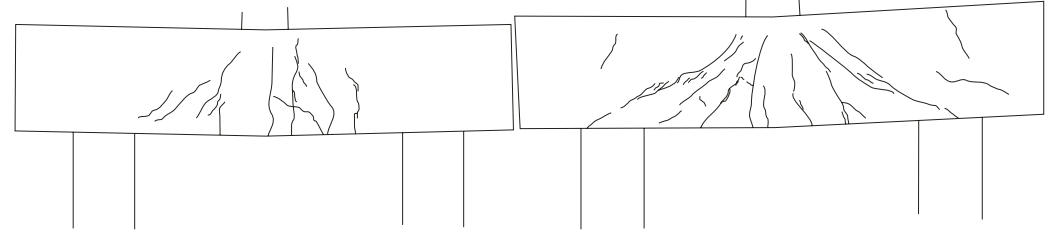

B4A1 Front

B4A1 Back

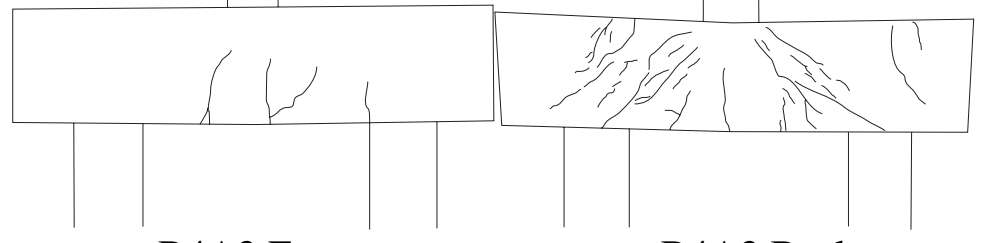

B4A2 Front

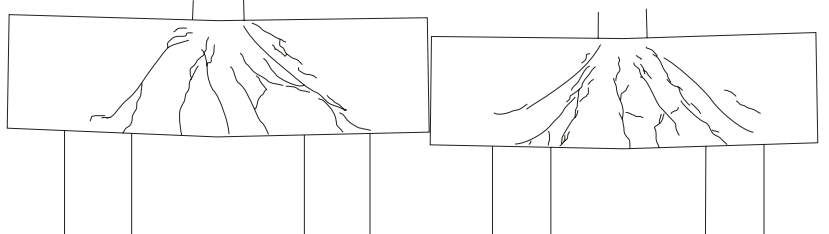

B4A3 Front

B4A3 Back
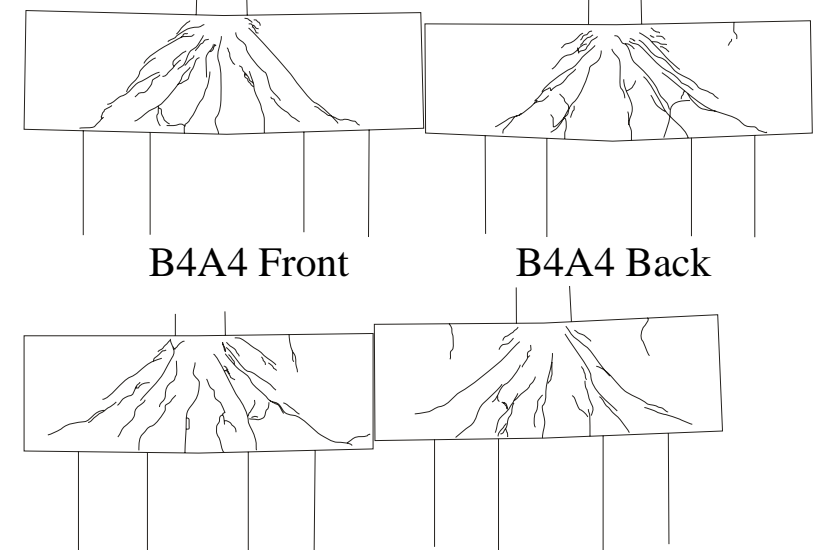

B4A5 Front

B4A5 Back

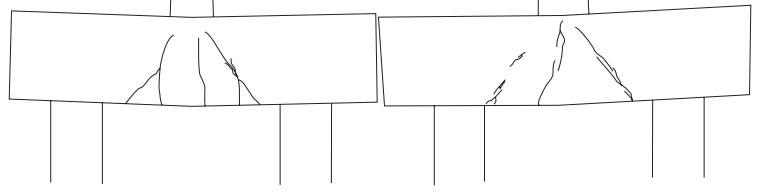

B4B2 Front

B4B2 Back

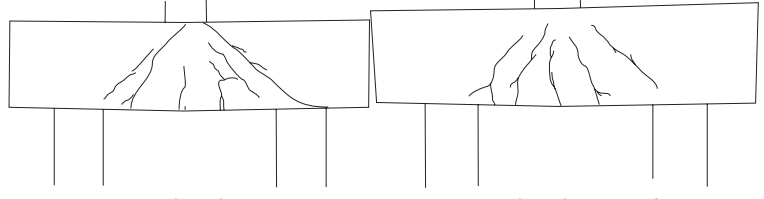

B4B3 Front

B4B3 Back

Fig.7 Crack Patterns at Failure Load throughout, at $50 \mathrm{kN} / \mathrm{min}$ or $1 \mathrm{~mm} / \mathrm{min}$.

Vertical deflection of fifteen key points on the soffit of the cap was measured by potentiometers and recorded in real time on a datalogger. The load measured by the testing machine's load cell was also continuously recorded. Crack propagation on the front and rear faces was noted and recorded by digital camera at each loading stage.

\section{Experimental Results}

\subsection{Crack Propagation}

Since a wall load is applied, the cap behaves more closely to a twodimensional deep beam than the situation when a concentrated load is applied. This means, as the final crack results show, that cracks on the front and back surfaces (Figure 3) can give important information explaining the mechanism of shear behaviour. In this paper, the type of crack is classified into three types: bending cracks, Kani tooth cracks [9] and compressive splitting cracks. (Diagonal tensile cracks have not been observed except on B4A1 back surface.)

In every case, cracking initiated with bending cracks from the cap soffit at midspan.

The occurrence of Kani tooth cracks in the tests is a debatable point. In shallow beams, Kani cracks are normally readily discernable, and are regarded as a transitional crack type linking bending cracks and shear cracks. In

these tests on relatively deep pile caps, Kani cracks are less apparent, but still appear to occur, in a form shorter and at steeper inclination than in a shallow beam, starting at the soffit of the cap near the first bending crack and then extending upwards at an angle towards the edge of the loaded area. This propagation normally occurred for a while and then stopped, being superseded by shear splitting crack propagation. As a character of a deep beam, Kani cracks are less densely distributed than in a shallow beam. This is because the short span constrains them from fully developing; or put in other words, compressive strut formation precedes the appearance of arch action. 
Compressive splitting cracks, which are essentially due to strut action, initiate first at the mid-height of the cap body and then propagate in both directions towards the pile head and the loaded area. In some cases (for example B4A4 and B4A5), the cracks propagate right across the head of the pile, the inclination reducing as they do so. Cracks also propagated downwards from the top surface of the cap above the pile position in some cases, indicating the existence of a hogging moment implying moment restraint at the pile head as mentioned in section 4.

A summary of the types of cracks typically formed is shown in Figure 6. Figure 7 shows the cracks observed on the front and back surface of each of the tested caps in Series A and B.

Even though crack monitoring showed that major bending cracks usually open widely, indicating reinforcement yield at the final stage, it is shear cracks that are growing most rapidly as the ultimate load is approached in most situations (except B4B2), and it is thus reasonable to regard the final failure mechanism as being by shear. Asymmetric crack distribution between the front and back of the cap shows that in some situations either the external force is not applied symmetrically, or the cap has asymmetric strength. The final crack descriptions and failure types are listed in Table 3.

Table 3 Failure Load and Failure Type

\begin{tabular}{|c|c|c|}
\hline $\begin{array}{l}\text { Pile Cap } \\
\text { Numbering }\end{array}$ & $\begin{array}{c}\text { Failure } \\
\text { Load } \\
\text { (KN) }\end{array}$ & Failure Type \\
\hline B4A1 & 592 & diagonal tensile shear failure on back surface left side \\
\hline B4A2 & 548 & compressive splitting shear failure on back surface left side \\
\hline B4A3 & 919 & compressive splitting shear failure on front surface right side \\
\hline B4A4 & 1052 & $\begin{array}{c}\text { compressive splitting shear failure on left side on front surface and right side on } \\
\text { back surface }\end{array}$ \\
\hline B4A5 & 1244 & compressive splitting shear failure on front surface right side \\
\hline B4B2 & 713 & bending failure on both surface \\
\hline B4B3 & 769 & compressive splitting shear failure on front surface \\
\hline
\end{tabular}

\subsection{Ultimate Load}

Table 4 lists the final failure loads and the ratio of investigated failure load over predicted load from the formulae (1) and (2) for shear design and from the truss method given in BS8110. In the bending design predictions, the partial factor $\gamma_{m}$ on concrete shear strength has been taken as 1.25.

Table 4 Comparison of Observed and Predicted Failure Loads ( $k N)$

\begin{tabular}{|c|c|c|c|c|c|c|c|}
\hline $\begin{array}{c}\text { Pile Cap } \\
\text { Specimen } \\
\text { Number }\end{array}$ & $\begin{array}{l}\text { Observed } \\
\text { Failure } \\
\text { Load }(\mathrm{kN})\end{array}$ & $\begin{array}{c}\text { BS8110 } \\
\text { Shear } \\
\text { Capacity } \\
\text { Prediction }\end{array}$ & $\begin{array}{l}\text { Observed } \\
\text { Failure } \\
\text { Load } \\
\text { Over } \\
\text { BS8110 } \\
\text { Prediction }\end{array}$ & $\begin{array}{l}\text { BS5400 } \\
\text { Shear } \\
\text { Capacity } \\
\text { Prediction }\end{array}$ & $\begin{array}{l}\text { Observed } \\
\text { Failure } \\
\text { Load } \\
\text { Over } \\
\text { BS5400 } \\
\text { Prediction }\end{array}$ & $\begin{array}{c}\text { BS8110 } \\
\text { Truss } \\
\text { Method } \\
\text { Prediction }\end{array}$ & $\begin{array}{c}\text { Observed } \\
\text { Failure } \\
\text { Load } \\
\text { Over } \\
\text { BS8110 } \\
\text { Truss } \\
\text { Method }\end{array}$ \\
\hline B4A1 & 592 & 185.7 & 3.17 & 175.4 & 3.36 & 615.5 & 0.96 \\
\hline B4A2 & 548 & 244.7 & 2.23 & 207.8 & 2.62 & 757.6 & 0.72 \\
\hline B4A3 & 919 & 310.5 & 2.96 & 243.9 & 3.77 & 895.3 & 1.03 \\
\hline B4A4 & 1052 & 358.7 & 3.04 & 270.4 & 4.03 & 984.9 & 1.11 \\
\hline B4A5 & 1244 & 520.2 & 2.35 & 359.0 & 3.39 & 1231.1 & 0.99 \\
\hline B4B2 & 713 & 273.0 & 2.60 & 225.8 & 3.14 & 623.9 & 1.14 \\
\hline B4B3 & 769 & 298.7 & 2.58 & 253.0 & 3.04 & 623.9 & 1.23 \\
\hline
\end{tabular}

$\gamma_{m}$ for the steel reinforcement is taken as 1.0, and its design strength, used to predict the strength by truss method, is then taken as the real yield strength from laboratory tests. 
Table 4 shows that the actual failure loads are at least twice the BS5400 and BS8110 shear strength predictions. This is despite the fact that some structures failed with an asymmetric crack distribution, indicating the potential for even higher failure loads to be achieved by symmetrical failure. The evidence implies that the semi-empirical formulae both in BS8110 and BS5400 conservatively estimate shear resistance of pile caps. In contrast, the predicted values from the truss method in BS8110 co-ordinates well with the actual failure loads, with the ratio shown in Table 4 varying between 0.72 and 1.23 .

\section{Conclusion}

A series of pile caps covering a range of dimensions have been tested to investigate pile cap shear behaviour and the validity of the shear strength design formulae given in UK design codes BS8110 and BS5400. Under a wall load uniformly distributed across its width, the three-dimensional pile cap behaves closely to a two-dimensional deep beam. Shear cracks (diagonal tensile crack and compressive splitting crack) appear in most samples. The actual failure loads observed were much higher than those predicted from semi-empirical formulae for shear capacity in both BS8110 and BS5400, and so therefore there is scope to advocate new design formulae based more closely on the true physical mechanism of shear resistance. The truss analogy gave much more reliable predictions of ultimate load.

\section{References}

[1] ADEBAR P., KUCHMA D., COLLINS M. P. " "Strut-and-Tie Models for the Design of Pile Caps: An Experimental Study." ACI STRUCTURAL JOUNAL, 1990, Jan-Feb, 87, No.1, 81-92.

[2] BLOODWORTH A.G., JACKSON. P. A., LEE M.M.K. "The Strength of Reinforced Concrete Pile Caps." Geotechnical Engineering 2003, 149(4), 1-13.

[3] CLARKE J.L. "Behaviour and Design of Pile Caps with Four Piles, Technical Report." 42.489,1973.

[4] HOBBS N.B., STEIN P. "An Investigation into the Stress Distribution in Pile Caps with Some Notes on Design." Proceedings of the Institution of Civil Engineers, 1957, 7, July, 599-628.

[5] BELVOT J., FREMY. R. Semelles Sur Pieux. Annales de l'Institut Technique du Batiment et des Travaux Publics, 1967, 20, No.230.

[6] SABINS G.M., GOGATE. A. B. "Investigation of Thick Slab (pile cap) Behaviour." ACI Journal, 1984, 81, No 1, 35-39.

[7] BS 8110-1:1997 (BRITISH STANDARD), Structural Use of Concrete-Part 1: Code of Practice for Design and Construction.

[8] BS 5400-4:1990 (BRITISH STANDARD), Steel, Concrete and Composite Bridges-Part 4: Code of Practice for Design of Concrete Bridges.

[9] KANI M.W., HUGGINS M. W., WITTKOPP P. F. "Kani on Shear in Reinforced Concrete." Department of Civil Engineering, University of Toronto, Canada, 1979. 